\title{
Genetic Analysis in Pre-breeding Lines of Greengram (Vigna radiata (L.) Wilczek.)
}

\author{
G. P. Harshitha and P. Jayamani* \\ Department of Pulses, Centre for Plant Breeding and Genetics, Tamil Nadu Agricultural \\ University, Coimbatore 641003, India \\ *Corresponding author
}

\section{A B S T R A C T}

\begin{tabular}{|l|}
\hline K e y w o r d s \\
Greengram, Inter \\
sub specific cross, \\
Pre-breeding lines, \\
Genetic variability, \\
Heritability, \\
Genetic advance \\
\hline Article Info \\
\hline $\begin{array}{l}\text { Accepted: } \\
\text { 22 June } 2020 \\
\text { Available Online: } \\
\text { 10 July } 2020\end{array}$ \\
\hline
\end{tabular}

Greengram is one of the most important pulse crops of India. It has low genetic variability and harvest inde $\mathrm{x}$ Interspecific crosses allows the exploitation of useful genes from wild species and to create the genetic variability in the cultivated ones. The hybridization was done between VBN (Gg) $2 \times$ Vigna radiata var. sublobata, a progenitor species of greengram used as a resistant parent for bruchid infestationto develop pre-breeding material. The stabilized lines of the above cross were evaluated during kharif, 2019 in Department of Pulses, Tamil Nadu Agricultural University, Coimbatore. A total of 53 inter sub specific lines were raised in randomized block design with two replications. Ten biometrical traits were recorded for all the 53 lines and were statistically analysed. A wide range of mean values were observed for all the traits. Phenotypic coefficient of variation (PCV) was higher than genotypic coefficient of variation (GCV) for all the characters indicating the influence of environment on all the traits. The traits viz., days to $50 \%$ flowering, plant height, number of clusters per plant, number of pods per plant, 100 seed weight and single plant yield showed high heritability coupled with high genetic advance as per cent of mean. The results on genetic analysis and trait based classification of prebreeding lines of the present study could be used to improve yield traits and bruchid resistance in greengram.

\section{Introduction}

Pulses are the most important crops next to cereals in the world. Among pulses, greengram (Vigna radiata (L.) Wilczek) occupies a prominent place in India. It has been cultivated since prehistoric periods and is believed to be a native crop of India (Vavilov, 1926). Greengram is third most important pulse crop in India after chickpea and pigeonpea in area and production. It is perfect combination of all nutrients, which includes proteins $(24-25 \%)$, CHO (56\%), fat $(1.3 \%)$, minerals, amino acids and vitamins (Paul et al., 2011)with low flatulence and high digestible nutrients. Protein is rich in the amino acid lysine which is predominantly deficient in cereal grains (Bhatty et al., 2000). Greengram seeds are rich in minerals viz., calcium, iron, magnesium, phosphorus and potassium and vitamins viz., ascorbic acid, thiamine, riboflavin, niacin, pantothenic acid 
and vitamin A (Tang et al., 2014). Presently, the yield of greengram is below the optimum level compare to other short duration pulses. Greengram is extensively grown because of its short duration and high adaptability to low water and fertility soils. India is the largest producer of greengram, covering an area about 4.25 million hectares with production of 2.01 million tones and productivity of 474 $\mathrm{kg} / \mathrm{ha}$ (Annual report, DPD, 2017-18).

Variability is the basic pre-requisite for the improvement of any population. Developing suitable selection strategy requires the knowledge of genetic variability and it can be assessed by calculating phenotypic coefficient of variation (PCV), genotypic coefficient of variation (GCV), heritability and genetic advance.

The extent of variability and heritability of the characters among the genotypes is the basic source for the exploitation of superior potentiality of genotypes. Calculation of GCV and PCV will gives the extent of environmental influence on the traits, whereas heritability gives the information on the magnitude of inheritance of quantitative traits, while genetic advance will be helpful in formulating suitable selection procedures.

\section{Materials and Methods}

The experimental material consists of inter sub specific lines of greengram obtained by crossing VBN $(\mathrm{Gg}) 2$ and Vigna radiata var. sublobata, a wild progenitor of greengram used as a resistant parent for bruchid infestation. A total of 53 stabilized prebreeding lines were raised in homogenous block following randomized block design (RBD) with two replications during kharif, 2019, in Department of Pulses, Centre for Plant Breeding and Genetics, Tamil Nadu Agricultural University, Coimbatore. The lines were planted in a row of $4 \mathrm{~m}$ in length with a spacing of $30 \times 10 \mathrm{~cm}$. All the agronomic practices were carried out timely to maintain the crop stand. Three plants were selected from each replication randomly to record the observations viz., days to 50 per cent flowering, plant height $(\mathrm{cm})$, number of branches per plant, number of clusters per plant, number of pods per cluster, number of pods per plant, pod length $(\mathrm{cm})$, number of seeds per pod, 100 seed weight (g) and yield per plant $(\mathrm{g})$.

The mean values of three plants were taken for the statistical analysis viz., mean and range (Panse and Sukhtame, 1961) phenotypic and genotypic variances (Goulden, 1952) phenotypic and genotypic coefficient of variability (Burton, 1952) heritability (Lush et al., 1940) genetic advance (Johnson et al., 1955) and genetic advance as per cent of mean, were adopted to find out the respective estimates.

\section{Results and Discussion}

Analysis of variance (ANOVA) for 53lines of greengram had highly significant values for all the 10 biometrical traits (Table 1). The existence of wide variability was observed with respect to different traits in the inter sub specific lines. The general mean value for each trait and its range among the lines is given in Table 2.

\section{Mean and range}

Mean performance of all 53 inter sub specific lines exhibited a wide range of variation for all the 10 biometrical traits viz., Days to $50 \%$ flowering (28.00 - 48.00), plant height (32.05 - $64.71 \mathrm{~cm})$, number of primary branches per plant (5.50 - 9.00), number of clusters per plant (3.83 - 9.50), number of pods per cluster (3.48 - 6.83), number of pods per plant (18.83 - 42.93), number of seeds per pod (9.33 14.33), pod length $(5.95-9.05 \mathrm{~cm})$, hundred 
seed weight(2.40 - $4.60 \mathrm{~g})$, single plant yield $(4.15$ - $8.57 \mathrm{~g})$. This indicates sufficient variation among the lines for the traits studied. This reflects that there is greater opportunity to improve yield and related traits in greengram (Table 2). Wide variation for the traits viz., days to $50 \%$ flowering, plant height, number of pods per plant and number of seeds per pod was observed by Sathya and Jayamani (2011), Susmitha and Jayamani (2018), Ramakrishnan et al., (2018), Manivelan et al., (2019) in greengram.

\section{Transgressive recombinants}

Gene pools are widened through hybridization of cultivars with wild species and exploited for improving many traits, including yield. Several reports are available on transgressive segregation for yield related traits from the crosses of cultivated and wild species. In the present investigation 31 transgressive recombinants were isolated for single plant yield which were above general mean.

A total of 26 transgressive segregants were identified as bold seeds with hundred seed weight exceeding the general mean $(3.30 \mathrm{~g})$ (Table 2). Thus these transgressive segregants could be used for yield improvement.

A total of 27 transgressive recombinants were found to be early flowering and 23 transgressive segregants with shorter plant height than the general mean which are preferable traits for inter cropping. Those transgressive recombinants which is short duration coupled with short plant stature could be tested in various inter cropping situations to identify the best performing transgressive recombinants.

Transgressive segregants with more primary branches and bearing more clusters have direct contribution towards yield. Thus 22 and 27 transgressive recombinants with more primary branches and clusters, respectively were identified for the improvement of greengram (Table 2).

Pods per plant is the primary yield contributing trait in greengram, 25 transgressive segregants recorded more pods per plant than the general mean (29.22). These transgressive segregants could be yield tested and further exploited for commercial cultivation. Pods per cluster contribute indirectly for yield improvement, 26 transgressive recombinants with more pods per cluster could be used in the breeding programme. Lengthy pods having more seeds per pod will increase the yield. Thus, the 27 transgressive segregants with more number of seeds per pod and 31 transgressive recombinants with increased pod length could be selected as pre-breeding material for the improvement of greengram (Table 2).

\section{Genetic variability}

The estimates of phenotypic coefficient of variation (PCV) were higher than the estimates of genotypic coefficient of variation (GCV) for all the traits under study indicating the environmental influence over the traits.

GCV was moderate for the characters days to 50 per cent flowering (14.98), plant height (17.03), number of clusters per plant (18.44), number of pods per cluster (14.07), number of pods per plant (18.20), hundred seed weight (15.84),single plant yield (13.46).

The PCV was moderate for the characters viz., days to $50 \%$ flowering (15.64), plant height (18.39), number of primary branches per plant (13.12), number of clusters per plant (19.31), number of pods per cluster (15.94), number of pods per plant (18.96), hundred seed weight (17.11), single plant yield (13.96), Selection will be effective based on the heritable nature of these traits. 
Table.1 Analysis of variance for yield and yield attributing traits in inter sub specific lines of greengram

\begin{tabular}{|c|c|c|c|c|c|c|c|c|c|c|c|}
\hline $\begin{array}{l}\text { Source of } \\
\text { variation }\end{array}$ & df & $\begin{array}{c}\text { Days to } \\
50 \% \\
\text { flowering }\end{array}$ & $\begin{array}{l}\text { Plant } \\
\text { height }\end{array}$ & $\begin{array}{c}\text { Numberof } \\
\text { primary } \\
\text { branches per } \\
\text { plant }\end{array}$ & $\begin{array}{c}\text { Number } \\
\text { of } \\
\text { clusters } \\
\text { per } \\
\text { plant }\end{array}$ & $\begin{array}{c}\text { Number } \\
\text { of pods } \\
\text { per } \\
\text { cluster }\end{array}$ & $\begin{array}{c}\text { Number } \\
\text { of pods } \\
\text { per } \\
\text { plant }\end{array}$ & $\begin{array}{l}\text { Number } \\
\text { of seeds } \\
\text { per pod }\end{array}$ & $\begin{array}{l}\text { Pod } \\
\text { length }\end{array}$ & $\begin{array}{c}\text { Hundredseed } \\
\text { weight }\end{array}$ & $\begin{array}{l}\text { Single } \\
\text { plant } \\
\text { yield }\end{array}$ \\
\hline Replication & 1 & 1.587 & 0.107 & 0.507 & 0.223 & 0.032 & 0.274 & 0.148 & 0.037 & 0.071 & 0.002 \\
\hline Treatment & 52 & $68.991 * *$ & $147.556^{* *}$ & $0.964 *$ & $3.056^{* *}$ & $1.301 * *$ & $59.023 * *$ & $1.944 * *$ & $0.921 * *$ & $0.595 * *$ & $1.978 * *$ \\
\hline Error & 52 & 2.979 & 11.331 & 0.5242 & 0.1422 & 0.161 & 2.423 & 0.057 & 0.067 & 0.045 & 0.72 \\
\hline
\end{tabular}

*significance at $5 \%$ level

**significance at $1 \%$ level

Table. 2 Coefficient of variation, heritability (broad sense), genetic advance, genetic advance as per cent of mean for yield and yield

component traits in inter sub specific lines of greengram

\begin{tabular}{|c|c|c|c|c|c|c|c|c|c|}
\hline S.No & Traits & General mean & Range & $\operatorname{PCV}(\%)$ & $\begin{array}{l}\text { GCV } \\
(\%)\end{array}$ & $\begin{array}{l}\text { Heritability } \\
(\%)\end{array}$ & $\begin{array}{c}\text { Genetic } \\
\text { advance } \\
\text { (GA) }\end{array}$ & $\begin{array}{l}\text { GA as per } \\
\text { cent of mean }\end{array}$ & $\begin{array}{c}\text { Number of lines } \\
\text { higher than } \\
\text { general mean }\end{array}$ \\
\hline 1 & Days to $50 \%$ flowering & $38.00 \pm 1.72$ & $28.00-48.00$ & 15.64 & 14.98 & 91.71 & 11.22 & 29.55 & 27 \\
\hline 2 & Plant height $(\mathrm{cm})$ & $48.45 \pm 3.36$ & $32.05-64.71$ & 18.39 & 17.03 & 85.74 & 15.74 & 32.49 & 30 \\
\hline 3 & $\begin{array}{l}\text { Number of branches per } \\
\text { plant }\end{array}$ & $6.57 \pm 0.72$ & $5.50-9.00$ & 13.12 & 7.14 & 29.59 & 0.52 & 8.00 & 22 \\
\hline 4 & $\begin{array}{l}\text { Number of clusters per } \\
\text { plant }\end{array}$ & $6.54 \pm 0.37$ & $3.83-9.50$ & 19.31 & 18.44 & 91.11 & 2.37 & 36.25 & 27 \\
\hline 5 & $\begin{array}{l}\text { Number of pods per } \\
\text { cluster }\end{array}$ & $5.36 \pm 0.40$ & $3.48-6.83$ & 15.94 & 14.07 & 77.91 & 1.37 & 25.59 & 26 \\
\hline 6 & Number of Pods per plant & $29.22 \pm 1.55$ & $18.83-42.93$ & 18.96 & 18.20 & 92.11 & 10.51 & 35.99 & 25 \\
\hline 7 & Number of Seeds per pod & $11.89 \pm 0.23$ & $9.33-14.33$ & 8.40 & 8.16 & 94.29 & 1.94 & 16.33 & 27 \\
\hline 8 & Pod length $(\mathrm{cm})$ & $7.41 \pm 0.25$ & $5.95-9.05$ & 9.48 & 8.81 & 86.45 & 1.25 & 16.89 & 31 \\
\hline 9 & Hundred seed weight (g) & $3.30 \pm 0.21$ & $2.40-4.60$ & 17.11 & 15.84 & 85.70 & 0.99 & 30.21 & 26 \\
\hline 10 & Single plant yield $(\mathrm{g})$ & $7.24 \pm 0.26$ & $4.15-8.57$ & 13.96 & 13.46 & 92.71 & 1.93 & 26.73 & 31 \\
\hline
\end{tabular}


Fig.1 Frequency distribution graph for the biometrical traits
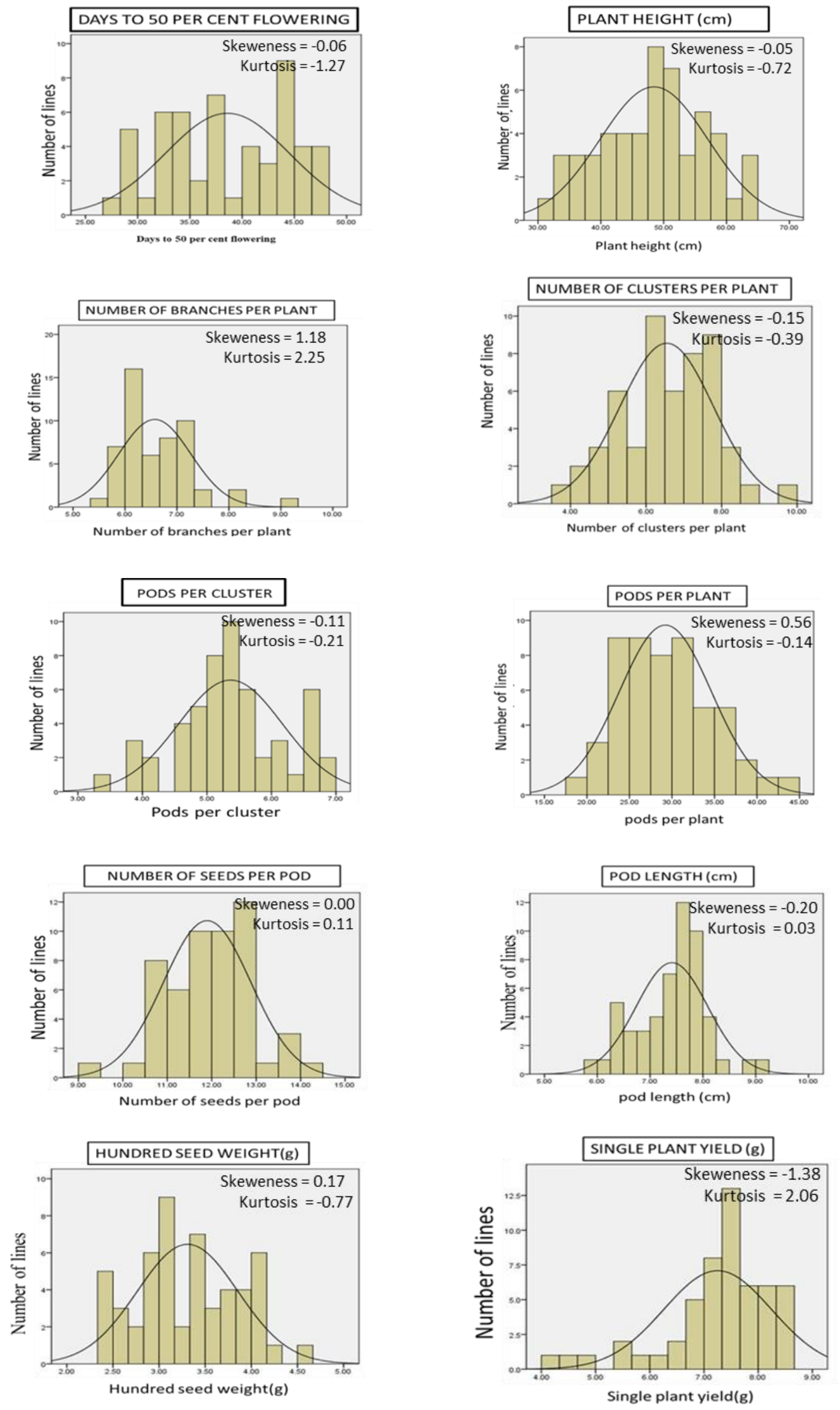
Low estimates of PCV and GCV was observed following characters viz., number of seeds per pod $(8.40,8.16$, respectively), pod length $(9.48,8.81$, respectively), These characters are highly influenced by the environment and selection would be ineffective (Table 2).

Heritability and genetic advance as percentage of mean (Per cent)

The estimates of heritability in broad sense for 10 characters are mentioned in Table 2 . The heritability estimates ranged from 94.29 to 29.59. The heritability was high for the characters viz., days to $50 \%$ flowering (91.71), plant height (85.74), number of clusters per plant (91.11), number of pods per cluster (77.91), number of pods per plant (92.11), number of seeds per pod (94.29), pod length (86.45), hundred seed weight(85.70), seed plant yield (92.71),Low heritability was exhibited by a single character viz., number of primary branches per plant (29.59). High heritability for the traits viz., number of pods per plant, pod length, hundred seed weight was observed by Tabasum et al., (2010).Kumar et al., (2013) and Muthuswamy et al., (2019), in greengram.

Genetic advance as per cent of mean for different traits revealed that it varied from 8.00 to 36.25 . The genetic advance as per cent of mean was high for the characters viz., days to 50 per cent flowering (29.55), plant height (32.49), number of clusters per plant (36.25), number of pods per cluster (25.59), number of pods per plant (35.99), hundred seed weight (30.21), single plant yield (26.73). Low genetic advance as per cent of mean was exhibited for following character viz., number of primary branches per plant (8.00). Moderate genetic advance as per cent of mean was depicted by the characters viz., number of seeds per pod (16.33) and pod length (16.89).
High heritability coupled with high genetic advance was exhibited by the characters viz., days to 50 per cent flowering $(91.71,29.55$, respectively), plant height $(85.74,15.74$, respectively), number of clusters per plant (91.11,36.25,respectively), number of pods per cluster $(77.91,25.59$, respectively), number of pods per plant (92.11, 35.99, respectively), hundred seed weight (85.70, 30.21 , respectively), single plant yield (92.71, 26.73, respectively), In these characters selection may be effective due to additive gene effects.

High heritability coupled with moderate genetic advance as per cent of mean was exhibited by the characters viz., number of seeds per pod $(94.29,16.33$, respectively) and pod length $(86.45,16.89$, respectively).

The following characters viz., number of primary branches per plant possessed low heritability coupled with low genetic advance as per cent of mean $(29.59,8.00$, respectively).

\section{Frequency distribution of traits}

Skewness and kurtosis were studied for 10 biometrical traits. Among the traits, normal population distribution was observed for days to 50 per cent flowering (-0.06), plant height $(-0.05)$, number of clusters per plant $(-0.15)$, number of pods per cluster $(-0.11)$, seeds per pod (0.00), pod length $(-0.20)$, hundred seed weight (0.17). Positive skewness was observed for the characters viz., number of branches per plant (1.18) and number of pods per plant (0.56). Negative skewness was recorded for single plant yield (-1.38) (Fig 1).

In case of kurtosis, all the characters showed positive value except for days to 50 per cent flowering, plant height and hundred seed weight. All the characters were mesokurtic in nature (Fig 1). 
Based on the present study, the pre-breeding lines with better mean values for yield attributing traits will be helpful in developing high yielding varieties of greengram. Hence, selection can be done on the basis of characters which shows high heritability coupled with high genetic advance as per cent of mean viz., days to 50 per cent flowering, plant height, number of clusters per plant, number of pods per cluster, number of pods per plant, hundred seed weight, single plant yield. Therefore, due emphasis is to be paid on above mentioned characters for improving the productivity during selection. Further prebreeding lines could be used for the improvement of yield traits and bruchid resistance in greengram.

\section{References}

Bhatty N, Gilani AH and Ahmad Nagra S. 2000. Nutritional value of mung bean (Vigna radiata) as effected by cooking and supplementation. Archivos latino americanos de nutricion 50 (4): 374-379

BurtonGW.1952. Quantitative inheritance in grasses. Proceedings of the International Grassland Congress 1:277283

Comstock RE and Robinson HF. 1948. The components of genetic variance in populations of bi-parental progenies and their use in estimating the average degree of dominance. Biometrics4: 254266

Goulden CH. 1952. Methods of Statistical Analysis. 1st Edn. John Wiley and Sons, Inc., New York, USA

Johnson HW, Robinson HF and Comstock RE. 1955. Estimation of genetic and environmental variability in soybeans. Archives of Agronomy and Soil Science47: 314-318

Kumar K, Prasad Y, Mishra SB, Pandey SS and Kumar R.2013. Study on genetic variability, correlation and path
Analysis with grain yield and yield attributing traits in green gram [Vigna Radiata (L) Wilczek]. The Bioscan 8(4): 1551-1555

Lush JL. 1940. Intrasine correlation and regression of offspring on dams as a method of estimating heritability of character. Proceedings of the American society of animal nutrition. 32: 293-301

Manivelan K, Karthikeyan M, Blessy V, Priyanka AR, Palaniyappan $\mathrm{S}$ and ThangavelP. 2019. Studies on correlation and path analysis for yield and yield related traits in greengram [Vigna radiata (L.) Wilczek]. The Pharma Innovation Journal. 8(9): 165167

Muthuswamy A, Jamunarani $M$ and Ramakrishnan P. 2019. Genetic Variability, Character Association and Path Analysis Studies in Green Gram (Vigna radiata (L.) Wilczek). International Journal of current Microbiology and Applied sciences 8(04): 1136-1146

Panse VG, Sukhatme PV and Shaw FJF.1961. Statistical Methods for Agricultural Workers: By VG Panse and PV Sukhatme. Indian Council of Agricultural Research.

Paul T, Mozumder NR, Sayed MA, Akhtaruzzaman $\mathrm{M}$ and Akhtaruzzaman MSM. 2011. Proximate compositions, mineral contents and determination of protease activity from green gram (Vigna radiata L. Wilczek). Bangladesh Journal of Agricultural Research. 5: 207-213

Ramakrishnan CD, Savithramma DL and Vijayabharathi A. 2018. Studies on genetic variability, correlation and path analysis for yield and yield related traits in Greengram [Vigna radiata (L.) Wilczek]. International Journal of Current Microbiology and Applied sciences. 7(3): 2753-2761 
Sathya M and Jayamani P. 2011. Heterosis and combining ability studies in greengram. Journal of Food Legumes. 24(4): 282-287

Susmitha D and Jayamani P. 2018. Genetic variability studies for yield and its contributing traits in greengram [Vigna radiata (L.) Wilczek]. Electronic Journal of PlantBreeding. 9(2): 716-722

Tabasum A, Saleem M and Aziz I. 2010. Genetic variability, trait association and path analysis of yield and yield components inmungbean (Vigna radiata (L. Wilczek). Pakistan Journal of Botany. 42(6): 3915-3924

Tang D, Dong Y, Ren H, Li L and He C. 2014. A review of phytochemistry, metabolite changes, and medicinal uses of the common food mung bean and its sprouts (Vigna radiata). Chemistry Central Journal, 8(1): 4

\section{How to cite this article:}

Harshitha, G. P. and Jayamani, P. 2020. Genetic Analysis in Pre-breeding Lines of Greengram (Vigna radiata (L.) Wilczek.). Int.J.Curr.Microbiol.App.Sci. 9(07): 2791-2798.

doi: https://doi.org/10.20546/ijcmas.2020.907.329 